\title{
Machine strength grading of Argentinean Eucalyptus grandis
}

\section{Main grading parameters and analysis of strength profiles according to European standards}

Published online: 9 December 2003

(C) Springer-Verlag 2003

\begin{abstract}
The present paper reports the results of an investigation regarding the possibility of machine strength grading sawn timber of Argentinean Eucalyptus grandis. In order to assess the usefulness of each parameter for predicting the mechanical properties of this timber species, and to propose strength, stiffness and density profiles, an empirical research project with four samples of beams and one sample of boards subjected to bending, and another sample of boards subjected to tension parallel to the grain, was carried out. The results obtained with specimens in structural sizes reveal the more important single and combined parameters for machine strength grading this timber species, and allow to analyse strength, stiffness and density profiles in comparison with the international strength class system established in the European standard EN 338.
\end{abstract}

\section{Maschinelle Festigkeitssortierung von Eucalyptus grandis aus Argentinien Sortierparameter und Festigkeitsprofile nach EN 388}

Zusammenfassung In diesem Beitrag wird über die Ergebnisse einer Untersuchung im Hinblick auf die Möglichkeiten für eine maschinelle Festigkeitssortierung von Eucalyptus grandis aus Argentinien berichtet. Zur Bewertung der Qualität der verschiedenen Parameter zur Vorhersage der mechanischen Eigenschaften dieser Holzart und zur Entwicklung von Festigkeitsprofilen wurde

\section{J. C. Piter}

Departamento de Ingeniería Civil,

Facultad Regional Concepción del Uruguay,

Universidad Tecnológica Nacional,

Ing. Pereira 676, (E3264BTD) C. del Uruguay,

Entre Ríos, Argentina

\section{R. L. Zerbino}

Departamento de Ingeniería Civil, Facultad de Ingeniería, Universidad Nacional de La Plata,

48 y 115, (1900) La Plata, Buenos Aires, Argentina

\section{H. J. Blaß (๘)}

Lehrstuhl für Ingenieurholzbau und Baukonstruktionen, Universität Karlsruhe, 76128 Karlsruhe, Germany

e-mail: hans.blass@holz.uka.de eine empirische Studie durchgeführt. Die experimentellen Untersuchungen umfassten vier Teilstichproben für Biegeversuche mit Kanthölzern und jeweils eine Teilstichprobe für Biege- und Zugversuche mit Brettern. Aus den Ergebnissen der Versuche mit Prüfkörpern in Bauteilabmessung lassen sich die wichtigsten maschinellen Sortierparameter für diese Holzart erkennen. Darüber hinaus wird eine Einteilung in Festigkeitsklassen nach der Europäischen Norm EN 338 ermöglicht.

\section{Introduction}

Paper 1 of this series (Piter et al. submitted to Holz als Roh- und Werkstoff) reported on the design of a method for visually grading sawn timber of this timber species. The increasing importance of quality assurance for structural timber, and the improvement of accuracy obtained with machine strength grading processes in comparison with the visual ones (Glos 1995), account for the convenience of scrutinising the possibility of machine strength grading this sawn timber species. This method also allows to classify timber in higher strength classes than based on visual strength grading and, consequently, the material can improve its competitiveness and value in the market in comparison with other building materials (Diebold and Glos 1994; Glos and Burger 1998; Görlacher 1990; Sauter and Diebold 1997). Machine grading is in common use in a number of countries and there is currently a growing tendency towards the utilisation of a strength class system as that established in the European standard EN 338 (1996). General requirements for machine strength grading are laid down in the European standard prEN 14081-1 (2000), and the strength-reducing characteristic that can not be detected by the machine must be sensed by a complementary visual inspection, according to the methods described in the European standard EN 1310 (1997).

There are currently different types of grading machines in use (Diebold 1997; Glos 1995; Görlacher 1997). The bending machines determine the average modulus of 
elasticity over lengths of $0.5 \mathrm{~m}$ to $1.2 \mathrm{~m}$. During the passage through the machine either a constant load acts on the timber and deflection is recorded at regular intervals, or the load is measured when a constant deflection is applied (Glos 1995). The ground of this type of machines is based on the high correlation that modulus of elasticity normally has with strength, but the incorporation of other grading parameters in combination with the modulus of elasticity, as density and knot ratio, allows to achieve higher correlation coefficients with strength than modulus of elasticity by itself (Glos and Diebold 1994). Results of many studies connected with the determination of the machine grading parameters allow to determine also accurately the average modulus of elasticity by dynamic methods, such as vibration, among others. Knots may be measured according to different criteria by radiation or optical scanning, while bulk density may be calculated by radiation or weighing. These new techniques make it possible to classify pieces with large cross sectional dimensions and allow to measure the main strength-reducing characteristics, such as knots, according to different criteria (Blaß and Görlacher 1996).

The aim of this paper is to present and discuss the results of an investigation regarding the usefulness of the main single and combined parameters for machine strength grading sawn timber of Argentinean Eucalyptus grandis, and to determine strength, stiffness and density profiles according to the European standards.

\section{Materials and methods}

Materials and methods were described in paper 1. In the present investigation the same data corresponding to 200 beams (samples 1 to 4) and 299 boards (samples 5 and 6) were used. With the aim to search for the highest correlation with strength, knot ratio was expressed according to ten different criteria. Four of them suitable for applying to both boards and beams: K, KAR 1, KAR 2 and KAR 3, which were described in paper 1. Two criteria were only applied to beams: i) Relation of the smallest diameter of the greatest knot and the width or thickness of the surface on which it appears. For edge knots the lower value was considered between the smallest diameter and the width of the knot measured between lines enclosing it and parallel to the edges of the piece (Kbe), ii) largest area of the projection of all knots or portions of knots intersected in a margin area, which adjoins the edges of a cross section and occupies one-quarter of the total area, divided by this margin area, without overlapping (KARbe). Another four criteria were only applied to boards: i) Sum of the dimensions of the greatest knot in all surfaces on which it appears divided by two times the width of the board. The dimension of the knot was measured between lines enclosing it and parallel to the edges of the piece (Kbo1), ii) the same criterion as the preceding one, but applied to the sum of all knots in any $150 \mathrm{~mm}$ of length of the specimen, without overlapping (Kbo2), iii) Average of the widths of the greatest knot on the two opposite faces, each width being taken between lines parallel to the edges of the board, divided by the width of the board. Dimensions of knots were disregarded when appearing on the thickness of the board (Kbo3), iv) relation of the largest dimension of a knot, or sum of knots intersected by a cross section, on a width and the width of the piece, being measured the dimension of eachthe knot between lines enclosing it and parallel to the edges of the piece. Dimensions of knots were disregarded when appearing on the thickness of the board (Kbo4). In all cases knot ratio was calculated with the knots located in the central third for specimens of samples subjected to bending tests, and with the knots located in the clear length between machine grips for specimens subjected to tension tests.

\section{Results and discussion}

The main results for the strength-reducing characteristics that must be sensed by a complementary visual inspection according to the European standard prEN 14081-1 (2000) and the values for mechanical and density properties of the 5 samples subjected to bending tests were presented in paper 1.

Table 1 shows the main data for studying the usefulness of the grading parameters for predicting bending strength $\left(\mathrm{f}_{\mathrm{m}}\right)$ in a machine grading process. Correlation coefficients between both single and combined parameters and bending strength are shown separately for each sample, and also for all beams and for the whole sample. The global modulus of elasticity $\left(\mathrm{E}_{\mathrm{m}, \mathrm{g}}\right)$ exhibits very good values for beams of Sample 1 and 2 and boards of Sample 5, and medium ones for sample 3 and 4 , coinciding in these both cases with the presence of a high percentage of large fissures. Density $(\rho)$ shows a very low value of 0.11 for Sample 4 and normal ones for all other individual samples. Knot ratio presents greater values for boards than for each sample of beams, with the particularity that positive correlation was found for criteria K and Kbe in Sample 1 and KAR1 and KAR2 in Sample 4. These particular values obtained for each sample of beams may be affected by the reduced number of specimens and, consequently, hereafter the analysis will be presented for all beams, boards and the whole sample. Correlation coefficients increase significantly when considering only the specimens free of visual features exceeding the limits established for strength classes above $\mathrm{C} 18$ as is indicated separately for all beams, boards and all samples in Table 1. Taking into account that beams present higher percentage of large fissures than boards, the correlation improvement is also higher for all beams than for boards of Sample 5. Since machine strength grading processes aim at obtaining better yields in high strength classes than those achieved by the visual ones, and considering the improvement obtained for the correlation between the grading parameters and bending strength after disregarding the pieces with the above mentioned visual defects, hereafter the analysis will 
Table 1 Correlation coefficients between the grading parameters and bending strength corrected to a reference depth of $150 \mathrm{~mm}$ according to EN 384 (1996). Values of the parameters $\mathrm{E}_{\mathrm{m}, \mathrm{g}}$ and $\rho$ are corrected to a reference moisture content of $12 \%$ according to EN 384 (1996); (1) Values corresponding to specimens free of visual characteristics exceeding the limits established in prEN 14081-1 (2000) for strength classes above C18
Tabelle 1 Korrelationskoeffizienten zwischen Sortierparametern und Biegefestigkeit korrigiert auf eine Bezugshöhe von $150 \mathrm{~mm}$ nach EN 384 (1996). Elastizitätsmodul $\mathrm{E}_{\mathrm{m}, \mathrm{g}}$ und $\rho$ sind auf eine Bezugsfeuchte von 12\% nach EN 384 (1996) korrigiert; (1) Werte für Prüfkörper ohne Merkmale, die die Grenzen in prEN 14081-1 (2000) für Festigkeitsklassen oberhalb von C18 überschreiten

\begin{tabular}{|c|c|c|c|c|c|c|c|}
\hline \multirow[t]{2}{*}{ Parameter } & \multicolumn{4}{|c|}{ Samples 1, 2, 3 and 4} & \multirow{2}{*}{$\begin{array}{l}\text { All beams } \\
n=200 / 119^{(1)}\end{array}$} & \multirow{2}{*}{$\begin{array}{l}\text { Sample 5 } \\
n=149 / 136^{(1)}\end{array}$} & \multirow{2}{*}{$\begin{array}{l}\text { All samples } \\
n=349 / 255^{(1)}\end{array}$} \\
\hline & $n=50 \mathrm{f}$ & ch sam & & & & & \\
\hline $\mathrm{E}_{\mathrm{m}, \mathrm{g}}$ & 0.82 & 0.84 & 0.61 & 0.66 & $0.77 / 0.83^{(1)}$ & $0.80 / 0.81^{(1)}$ & $0.77 / 0.81^{(1)}$ \\
\hline$\rho$ & 0.53 & 0.34 & 0.57 & 0.11 & $0.38 / 0.46^{(1)}$ & $0.47 / 0.48^{(1)}$ & $0.42 / 0.46^{(1)}$ \\
\hline K & 0.12 & -0.32 & -0.16 & -0.22 & $-0.21 /-0.29^{(1)}$ & $-0.50 /-0.54^{(1)}$ & $-0.32 /-0.39^{(1)}$ \\
\hline KAR1 & -0.15 & -0.29 & -0.20 & 0.05 & $-0.25 /-0.36^{(1)}$ & $-0.43 /-0.44^{(1)}$ & $-0.30 /-0.40^{(1)}$ \\
\hline KAR2 & -0.14 & -0.30 & -0.11 & 0.05 & $-0.23 /-0.36^{(1)}$ & $-0.47 /-0.49^{(1)}$ & $-0.30 /-0.42^{(1)}$ \\
\hline KAR3 & -0.22 & -0.35 & -0.07 & -0.03 & $-0.27 /-0.40^{(1)}$ & $-0.49 /-0.50^{(1)}$ & $-0.33 /-0.44^{(1)}$ \\
\hline Kbe & 0.06 & -0.36 & -0.20 & -0.13 & $-0.26 /-0.38^{(1)}$ & - & - \\
\hline KARbe & -0.11 & -0.41 & -0.14 & -0.05 & $-0.30 /-0.47^{(1)}$ & - & - \\
\hline Kbo1 & - & - & - & - & - & $-0.39 /-0.43^{(1)}$ & - \\
\hline Kbo 2 & - & - & - & - & - & $-0.51 /-0.52^{(1)}$ & - \\
\hline Kbo3 & - & - & - & - & - & $-0.42 /-0.46^{(1)}$ & - \\
\hline Kbo4 & - & - & - & - & - & $-0.50 /-0.55^{(1)}$ & - \\
\hline $\mathrm{E}_{\mathrm{m}, \mathrm{g}}+\rho$ & - & - & - & - & $0.77 / 0.84^{(1)}$ & $0.81 / 0.81^{(1)}$ & $0.77 / 0.81^{(1)}$ \\
\hline $\mathrm{E}_{\mathrm{m}, \mathrm{g}}+\mathrm{KAR} 3$ & - & - & - & - & - & - & $0.78 / 0.82^{(1)}$ \\
\hline $\mathrm{E}_{\mathrm{m}, \mathrm{g}}+\mathrm{KARbe}$ & - & - & - & - & $0.77 / 0.85^{(1)}$ & - & - \\
\hline $\mathrm{E}_{\mathrm{m}, \mathrm{g}}+\mathrm{Kbo} 2 / 4^{(1)}$ & - & - & - & - & - & $0.81 / 0.82^{(1)}$ & - \\
\hline$\rho+\mathrm{KAR} 3$ & - & - & - & - & - & - & $0.57 / 0.67^{(1)}$ \\
\hline$\rho+$ KARbe & - & - & - & - & $0.50 / 0.67^{(1)}$ & - & - \\
\hline$\rho+\mathrm{Kbo} 2 / 4^{(1)}$ & - & - & - & - & - & $0.74 / 0.73^{(1)}$ & - \\
\hline $\mathrm{E}_{\mathrm{m}, \mathrm{g}}+\rho+\mathrm{KAR} 3$ & - & - & - & - & - & - & $0.78 / 0.82^{(1)}$ \\
\hline $\mathrm{E}_{\mathrm{m}, \mathrm{g}}+\rho+\mathrm{KARbe}$ & - & - & - & - & $0.78 / 0.85^{(1)}$ & - & - \\
\hline $\mathrm{E}_{\mathrm{m}, \mathrm{g}}+\rho+\mathrm{Kbo} 2 / 4^{(1)}$ & - & - & - & - & - & $0.83 / 0.84^{(1)}$ & - \\
\hline
\end{tabular}

enclose only the correlation values corresponding to the specimens free of these visual characteristics.

Global modulus of elasticity is the main single parameter for predicting bending strength, with correlation coefficients of $0.83,0.81$ and 0.81 for all beams, boards and all samples respectively. Johansson et al. (1992) reported a value of 0.85 for a test series with German and Swedish Picea abies in structural sizes, whereas Glos and Diebold (1987) found values ranging from 0.71 to 0.82 for four test series involving timber of Picea abies and Pinus sylvestris. The correlation coefficients for density are $0.46,0.48$ and 0.46 for all beams, boards and the whole sample respectively, and they compare well with the value of 0.45 reported by Johansson et al. (1992) and are higher than those ranging from 0.23 to 0.44 reported by Glos and Diebold (1987), in both cases for the above mentioned test series. Knot ratio shows higher values for boards than for beams in the present study. KARbe $(-0.47), \mathrm{Kbo} 4(-0.55)$ and KAR3 (-0.44) exhibit the best correlation for all beams, boards and the whole sample respectively. Even though results indicate that strength and knot ratio are not highly related in this timber species, this correlation significantly improves when considering only the specimens free of large fissures and defects, which is of greater importance for beams than for boards. Glos and Lederer (2000) reported values of -0.64 and -0.69 for knot ratio calculated in the same way as KARbe for a test series with beams of oak and beech in structural sizes respectively, and values of -0.63 and -0.56 when the criterion coincides with KAR3. Glos and Diebold (1987) found values ranging from -0.40 to -0.60 and from -0.61 to -0.74 according to criterion KARbe and KAR3 respectively, for four test series involving timber of Picea abies and Pinus sylvestris.

The addition of two or more independent variables results generally in better correlation with strength than when considering them individually. By means of a multiple linear regression analysis the correlation coefficients between two or more combined parameters and the independent variable (bending strength) were determined and also presented in Table 1 . The combination of modulus of elasticity with density allow to reach correlation coefficients of $0.84,0.81$ and 0.81 for all beams, boards and all samples respectively, but values of 0.85 , 0.82 and 0.82 were obtained for the corresponding samples by adding modulus of elasticity with knot ratio, indicating a better correlation in the last case than in the previous one. When combining parameters knot ratio is considered as KARbe, Kbo4 and KAR3 for all beams, boards and all samples respectively, because they show the best individual correlation with strength. The addition of density with knot ratio produces the poorest results for combined variables, whereas modulus of elasticity with density and knot ratio shows the highest correlation coefficients, with values of $0.85,0.84$ and 0.82 for the three analysed groups of specimens. The last result of 0.82 found for all samples is in line with those ranging from 0.80 to 0.88 reported by Glos and Diebold (1987) for 
Table 2 Strength, stiffness and density profiles with the corresponding yield and limits for the grading parameters. Strength and stiffness values are expressed in $\mathrm{N} / \mathrm{mm}^{2}$, bulk density in $\mathrm{kg} / \mathrm{m}^{3}$, yield in number of specimens and percentage (\%); suffixes 075 and 05 indicate the lower 7.5th and 5th percentiles; (1) corrected to a reference depth of $150 \mathrm{~mm}$ according to EN 384 (1996); (2) corrected to a reference moisture content of $12 \%$ according to EN 384 (1996); (3) adjusted for sample size $\left(\mathrm{k}_{\mathrm{s}}\right)$ and machine strength grading $\left(\mathrm{k}_{\mathrm{v}}\right)$ according to EN 384 (1996); (4) number of specimens exceeding the limits for visual characteristics established in prEN 14081-1 (2000) for strength classes above C18

\begin{tabular}{|c|c|c|c|c|c|c|}
\hline & $\begin{array}{l}\text { Strength } \\
\text { class }\end{array}$ & Parameter limits & $\mathrm{f}_{\mathrm{m}, 075^{(1)}}$ & $\mathrm{E}_{\mathrm{m}, \mathrm{g}, \text { mean }}(2)$ & $\rho_{05}{ }^{(2)}$ & Yield \\
\hline a) & $\begin{array}{l}\text { C35 } \\
\text { C24 } \\
\text { C18 }\end{array}$ & $\begin{array}{l}\mathrm{GP} \geq 39.2 \\
39.2>\mathrm{GP} \geq 27.5 \\
\text { visual rejection and } \mathrm{GP}<27.5\end{array}$ & $\begin{array}{l}35.9 / 35.4^{(3)} \\
25.7 / 24.2^{(3)} \\
19.6 / 18.6^{(3)}\end{array}$ & $\begin{array}{l}14400 \\
11000 \\
11400\end{array}$ & $\begin{array}{l}440 \\
411 \\
423\end{array}$ & $\begin{aligned} & 159(62) \\
& 86(34) \\
& 10(4) / 94^{(4)}\end{aligned}$ \\
\hline b) & $\begin{array}{l}\text { C35 } \\
\text { C24 } \\
\text { C18 }\end{array}$ & $\begin{array}{l}E_{m, g} \geq 12300 \\
12300>E_{m, g} \geq 9370 \\
\text { visual rejection and } E_{m, g}<9370\end{array}$ & $\begin{array}{l}35.7 / 35.2^{(3)} \\
25.7 / 24.2^{(3)} \\
19.6 / 18.7^{(3)}\end{array}$ & $\begin{array}{l}14500 \\
11100 \\
11300\end{array}$ & $\begin{array}{l}444 \\
412 \\
420\end{array}$ & $\begin{aligned} & 154(60) \\
& 89(35) \\
& 12(5) / 94^{(4)}\end{aligned}$ \\
\hline
\end{tabular}

Tabelle 2 Festigkeits-, Steifigkeits und Rohdichteprofile mit der entsprechenden Ausbeute und Grenzen der Sortierparameter. Festigkeits- und Steifigkeitswerte in N/ $\mathrm{mm}^{2}$; Rohdichte in $\mathrm{kg} / \mathrm{m}^{3}$; Ausbeute als Anzahl der Prüfkörper und in Prozent (\%); Fußzeiger 075 und 05 bedeuten die untere $7.5 \%$ und 5\%-Quantile; (1) Korrigiert auf eine Bezugshöhe von 150 mm nach EN 384 (1996); (2) Korrigiert auf eine Bezugsfeuchte von $12 \%$ nach EN 384 (1996); (3) korrigiert für die Anzahl der Prüfkörper $\left(\mathrm{k}_{\mathrm{s}}\right)$ und Sortierverfahren $\left(\mathrm{k}_{\mathrm{v}}\right)$ nach EN 384 (1996); (4) Anzahl derjenigen Prüfkörper, die die Grenzen in prEN 14081-1 (2000) für Festigkeitsklassen oberhalb von $\mathrm{C} 18$ überschreiten four test series with timber of Picea abies and Pinus sylvestris in structural sizes.

Although beams and boards exhibit separately in some cases a better correlation between parameters and strength than when considering all samples, the number of pieces account for the convenience of going on the investigation for the specimens of all samples. The highest coefficient of determination between the analysed parameters and bending strength for all samples $(\mathrm{R}=0.82)$ is 0.67 . Knowing $\mathrm{E}_{\mathrm{m}, \mathrm{g}}, \rho$ and KAR3 explains therefore about $67 \%$ of the variability of the bending strength for the analysed specimens, and the estimated multiple regression model for expressing this combined grading parameter (GP) is:

$$
\begin{aligned}
\mathrm{GP}= & -6.7650+0.0032850 \mathrm{E}_{\mathrm{m}, \mathrm{g}} \\
& +0.015950 \rho-9.7890 \mathrm{KAR} 3
\end{aligned}
$$

A detailed analysis confirms a slightly lower value of 0.816 for the combination of $\mathrm{E}_{\mathrm{m}, \mathrm{g}}$ and KAR3 (0.82 in Table 1) than for GP. $E_{m, g}$ exhibits a correlation coefficient of 0.81 with strength by itself and, consequently, explains about $66 \%$ of the variability of the bending strength. These results account for the convenience of developing strength profiles on the base of GP and $E_{m, g}$ as grading parameters, disregarding the other single or combined ones because of their poor contribution to the results.

The high ratio of both modulus of elasticity and strength to density for this timber species accounts for the convenience of comparing bending strength, modulus of elasticity and density values with those corresponding to coniferous and poplar, even though it is necessary to determine the other additional properties (see paper 1). According to this, and in order to discuss different strength, stiffness and density profiles and the corresponding limits for the parameters, two different models are presented in Table 2. For comparing each profile with those belonging to the strength class system established in EN 338 (1996), the lower 7.5th percentile of bending strength, the mean value for $\mathrm{E}_{\mathrm{m}, \mathrm{g}}$ and the lower 5th percentile of bulk density are presented. Characteristic strength values were adjusted for sample size and machine strength grading according to EN 384 (1996).

A previous analysis showed that only 24 specimens could be assigned to strength class C40 considering GP as grading parameter, mainly because of the statistical penalisation $\left(\mathrm{k}_{\mathrm{s}}\right)$ for sample size according to EN 384 (1996) and, consequently, this strength class was disregarded as optimum grade. Profile a) shows that 159 and 86 pieces can be assigned to strength class C35 and C24 respectively, representing $62 \%$ and $34 \%$ of the graded specimens. This model allows to assign therefore 245 $(96 \%)$ of the graded specimens to the expected strength classes, rejecting only $10(4 \%)$ of the pieces, which, together with those disregarded by visual defects (94) may be assigned to the third grade. A detailed analysis of the yield for each sample subjected to bending tests is presented in Table 3, where it is possible to appreciate that only 3 specimens of Sample 1 and 7 of Sample 5 present values of GP less than the inferior limit for C24. This table also shows that more than $50 \%$ of the specimens of Sample 3 and 4 are rejected because of visual defects. Profile b) considers $\mathrm{E}_{\mathrm{m}, \mathrm{g}}$ as grading parameter and the yield is similar to the previous one. As it is indicated in Table 3, only 3 specimens of Sample 1 and 9 of Sample 5 of this profile present values of $E_{m, g}$ less than the inferior limit for $\mathrm{C} 24$.

Both models presented in profiles a) and b) allow to assign more than $60 \%$ of the graded specimens to the optimum grade (C35) and more than $30 \%$ to the second one $(\mathrm{C} 24)$. The third grade values are greater than the corresponding for strength class $\mathrm{C} 18$, but the presence of quality reducing features may be a reason of rejection for structural purposes (European Committee for standardisation 2000). In particular, there are 65 specimens with fissures exceeding the limits established in prEN 14081 for strength classes $\mathrm{C} 18$ and below, and 3 pieces with large defects. Taken into account that yields obtained in 
Table 3 Yield of the samples subjected to bending tests according to the analysed profiles, expressed in number of specimens. Parameter $\mathrm{E}_{\mathrm{m}, \mathrm{g}}$ is expressed in $\mathrm{N} / \mathrm{mm}^{2}$ and corrected to a reference moisture content of 12\% according to EN 384 (1996); (1) number of specimens exceeding the limits for visual characteristics established in prEN 14081-1 (2000) for strength classes above C18
Tabelle 3 Ausbeute der Teilstichproben mit Biegeversuchen in den entsprechenden Festigkeitsklassen, als Anzahl der Prüfkörper. $\mathrm{E}_{\mathrm{m}, \mathrm{g}}$ in $\mathrm{N} / \mathrm{mm}^{2}$ und korrigiert auf eine Bezugsfeuchte von $12 \%$ nach EN 384 (1996; (1) Anzahl derjenigen Prüfkörper, die die Grenzen in prEN 14081-1 (2000) für Festigkeitsklassen oberhalb von C18 überschreiten

\begin{tabular}{|c|c|c|c|c|c|c|c|}
\hline & $\begin{array}{l}\text { Strength } \\
\text { class }\end{array}$ & Parameter limits & S 1 & S 2 & S 3 & S 4 & S 5 \\
\hline a) & $\begin{array}{l}\mathrm{C} 35 \\
\mathrm{C} 24 \\
\mathrm{C} 18\end{array}$ & $\begin{array}{l}\mathrm{GP} \geq 39.2 \\
39.2>\mathrm{GP} \geq 27.5 \\
\text { visual rejection and } \mathrm{GP}<27.5\end{array}$ & $\begin{array}{l}16 \\
16 \\
3 / 15^{(1)}\end{array}$ & $\begin{array}{l}29 \\
10 \\
0 / 11^{(1)}\end{array}$ & $\begin{array}{l}14 \\
9 \\
0 / 27^{(1)}\end{array}$ & $\begin{array}{l}18 \\
4 \\
0 / 28^{(1)}\end{array}$ & $\begin{array}{l}82 \\
47 \\
7 / 13^{(1)}\end{array}$ \\
\hline b) & $\begin{array}{l}\text { C35 } \\
\text { C24 } \\
\text { C18 }\end{array}$ & $\begin{array}{l}E_{m, g} \geq 12300 \\
12300>E_{m, g} \geq 9370 \\
\text { visual rejection and } E_{m, g}<9370\end{array}$ & $\begin{array}{l}14 \\
18 \\
3 / 15^{(1)}\end{array}$ & $\begin{array}{l}29 \\
10 \\
0 / 11^{(1)}\end{array}$ & $\begin{array}{l}13 \\
10 \\
0 / 27^{(1)}\end{array}$ & $\begin{array}{l}18 \\
4 \\
0 / 28^{(1)}\end{array}$ & $\begin{array}{l}80 \\
47 \\
9 / 13^{(1)}\end{array}$ \\
\hline
\end{tabular}

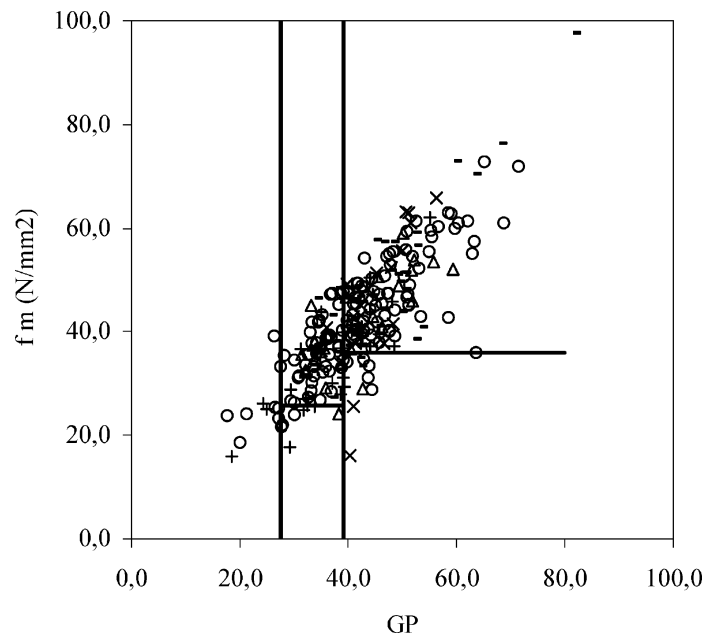

Fig. 1 Relationship between the combined grading parameter (GP) and bending strength $\left(f_{m}\right)$ for 255 specimens free of visual characteristics exceeding the limits established in prEN 14081 for strength classes above C18. Correlation coefficient: $0.82 ;(+),(-)$, $(\triangle),(3)$ and (o) indicate the specimens of Sample 1, 2, 3, 4 and 5 respectively; vertical lines show the inferior limit of GP corresponding to the first and second grade analysed in Table 4 (39.2 and 27.5 respectively), whereas horizontal lines indicate the corresponding lower 7.5 th percentiles for bending strength $\left(35.9 \mathrm{~N} / \mathrm{mm}^{2}\right.$ and $25.7 \mathrm{~N} / \mathrm{mm}^{2}$ respectively)

Abb. 1 Zusammenhang zwischen dem maschinellen Sortierparameter (GP) und der Biegefestigkeit $\left(\mathrm{f}_{\mathrm{m}}\right)$ für 255 Prüfkörper ohne visuelle Merkmale, die die Grenzen in prEN 14081 für Festigkeitsklassen oberhalb von $\mathrm{C} 18$ überschreiten. Korrelationskoeffizient $=0.82 ;(+),(-),(\triangle),(3)$ und $(\mathrm{o})$ bezeichnen die Prüfkörper der Teilstichproben 1, 2, 3, 4 und 5; vertikale Geraden zeigen die untere Grenze für GP für die erste und zweite Klasse nach Tabelle 4 (39.2 bzw. 27.5), horizontale Geraden bedeuten die entsprechenden unteren 7.5\%-Quantilen der Biegefestigkeit $\left(35.9 \mathrm{~N} / \mathrm{mm}^{2}\right.$ und $25.7 \mathrm{~N} / \mathrm{mm}^{2}$ )

profile a) are only slightly better than the corresponding in profile b), and considering the simplicity of employing $\mathrm{E}_{\mathrm{m}, \mathrm{g}}$ as grading parameter in comparison with GP, efficiency and price must be considered when comparing different types of grading processes and machines for this case. The decrease of large fissures by means of improving the drying processes appears to be more important for increasing yield than the adoption of a

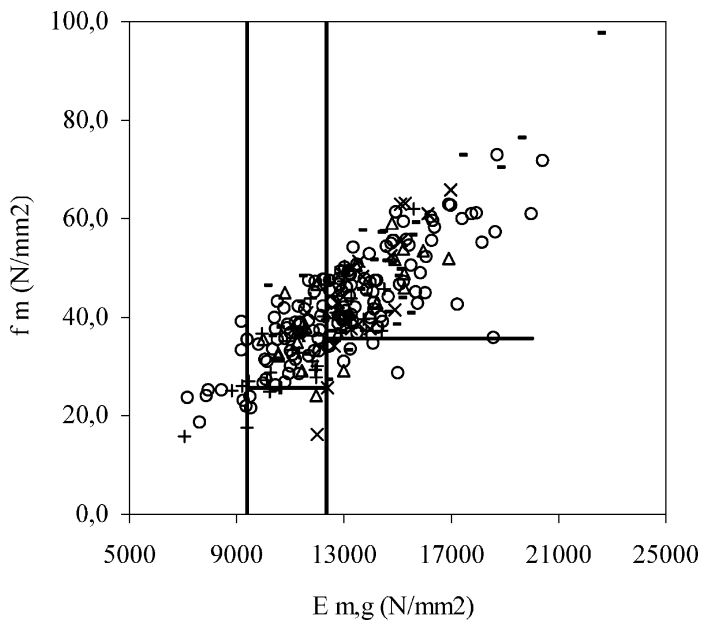

Fig. 2 Relationship between the global modulus of elasticity $\left(E_{m, g}\right)$ and bending strength $\left(f_{m}\right)$ for 255 specimens free of visual characteristics exceeding the limits established in prEN 14081 for strength classes above C18. Correlation coefficient: $0.81 ;(+),(-)$, $(\triangle),(3)$ and (o) indicate the specimens of Sample 1, 2, 3, 4 and 5 respectively; vertical lines show the inferior limit of $E_{m, g}$ corresponding to the first and second grade analysed in Table 4 $\left(12300 \mathrm{~N} / \mathrm{mm}^{2}\right.$ and $9370 \mathrm{~N} / \mathrm{mm}^{2}$ respectively), whereas horizontal lines indicate the corresponding lower 7.5th percentiles for bending strength $\left(35.7 \mathrm{~N} / \mathrm{mm}^{2}\right.$ and $25.7 \mathrm{~N} / \mathrm{mm}^{2}$ respectively)

Abb. 2 Zusammenhang zwischen dem globalen Elastizitätsmodul $\left(E_{m, g}\right)$ und der Biegefestigkeit $\left(f_{m}\right)$ für 255 Prüfkörper ohne visuelle Merkmale, die die Grenzen in prEN 14081 für Festigkeitsklassen oberhalb von $\mathrm{C} 18$ überschreiten. Korrelationskoeffizient $=0.81 ;(+)$, $(-),(\triangle),(3)$ und (o) bezeichnen die Prüfkörper der Teilstichproben $1,2,3,4$ und 5; vertikale Geraden zeigen die untere Grenze für $E_{m, g}$ für die erste und zweite Klasse nach Tabelle $4(12300$ N/mm² bzw. $9370 \mathrm{~N} / \mathrm{mm}^{2}$ ), horizontale Geraden bedeuten die entsprechenden unteren 7.5\%-Quantilen der Biegefestigkeit $\left(35.7 \mathrm{~N} / \mathrm{mm}^{2}\right.$ und $25.7 \mathrm{~N} / \mathrm{mm}^{2}$ )

complex model for machine grading this sawn timber species.

Figure 1 shows the relationship between the predicted (GP) and observed $\left(f_{m}\right)$ values of the dependent variable (bending strength). The inferior limit for the grading parameter and the strength lower 7.5th percentile corresponding to the first and second grade are indicated by means of vertical and horizontal lines, respectively. In Fig. 2 the relationship between the global modulus of 
Table 4 Strength, stiffness, density and yield values for boards of Sample 6 subjected to tension parallel to the grain, according to the profiles analysed for samples 1 to 5 but replacing $E_{m, g}$ with $E_{t .0}$ in the parameter models. Strength and stiffness values are expressed in $\mathrm{N} / \mathrm{mm}^{2}$, density in $\mathrm{kg} / \mathrm{m}^{3}$, yield in number of specimens and percentage (\%); (1) corrected to a reference width of $150 \mathrm{~mm}$ according to EN 384 (1996); (2) corrected to a reference moisture content of 12\% according to EN 384 (1996); (3) number of specimens exceeding the limits for visual characteristics established in prEN 14081-1 (2000) for strength classes above C18; (4) the smallest value for $\mathrm{n}<20$

\begin{tabular}{|c|c|c|c|c|c|c|}
\hline Profile & $\begin{array}{l}\text { Strength } \\
\text { class }\end{array}$ & Parameter limits & $\mathrm{f}_{\mathrm{t} .0,05}{ }^{(1)}$ & $\mathrm{E}_{\mathrm{t} .0, \text { mean }}(2)$ & $\rho_{05}{ }^{(2)}$ & Yield \\
\hline a) & $\begin{array}{l}\text { C35 } \\
\text { C24 } \\
\text { C18 }\end{array}$ & $\begin{array}{l}\mathrm{GP} \geq 39.2 \\
39.2>\mathrm{GP} \geq 27.5 \\
\text { visual rejection and } \mathrm{GP}<27.5\end{array}$ & $\begin{array}{l}22.2 \\
16.2 \\
11.9\end{array}$ & $\begin{array}{l}15000 \\
11300 \\
11400\end{array}$ & $\begin{array}{l}478 \\
426 \\
467\end{array}$ & $\begin{aligned} 85 & (63) \\
43 & (32) \\
7 & (5) / 15^{(3)}\end{aligned}$ \\
\hline b) & $\begin{array}{l}\text { C35 } \\
\text { C24 } \\
\text { C18 }\end{array}$ & $\begin{array}{l}\mathrm{E}_{\mathrm{t} .0} \geq 12300 \\
12300>\mathrm{E}_{\mathrm{t} .0} \geq 9370 \\
\text { visual rejection and } \mathrm{E}_{\mathrm{t} .0}<9370\end{array}$ & $\begin{array}{r}23.7 \\
15.9 \\
9.5^{(4)}\end{array}$ & $\begin{array}{l}15200 \\
11300 \\
11600\end{array}$ & $\begin{array}{l}480 \\
432 \\
459\end{array}$ & $\begin{array}{l}80(59) \\
51(38) \\
4(3) / 15^{(3)}\end{array}$ \\
\hline
\end{tabular}

Tabelle 4 Festigkeits-, Steifigkeits und Rohdichtewerte der für Bretter der Teilstichprobe 6 unter Zugbeanspruchung, entsprechend den Profilen für Teilstichproben 1 bis 5; $\mathrm{E}_{\mathrm{m}, \mathrm{g}}$ wurde durch $\mathrm{E}_{\mathrm{t} .0}$ in den Modellen ersetzt. Festigkeit und Steifigkeit in $\mathrm{N} / \mathrm{mm}^{2}$, Rohdichte in $\mathrm{kg} / \mathrm{m}^{3}$, Ausbeute als Anzahl der Prüfkörper und in Prozent (\%); (1) Korrigiert auf eine Bezugshöhe von $150 \mathrm{~mm}$ nach EN 384 (1996); (2) Korrigiert auf eine Bezugsfeuchte von 12\% nach EN 384 (1996); (3) Anzahl derjenigen Prüfkörper, die die Grenzen in prEN 14081-1 (2000) für Festigkeitsklassen oberhalb von $\mathrm{C} 18$ überschreiten; (4) Kleinstwert für $\mathrm{n}<20$ elasticity $\left(E_{m, g}\right)$ and bending strength $\left(f_{m}\right)$ is shown. The limits for the parameter and the lower 7.5th percentiles for bending strength are indicated in the same way as in Fig. 1. These two figures allow to appreciate the very good correlation between both parameters and bending strength, and the excellent yield obtained with the specimens free of visual characteristics exceeding the limits established in prEN 14081 for strength classes above $\mathrm{C} 18$. These results prove that this timber species may advantageously perform in a machine strength grading process, even though the final efficiency of the method will be related to the type and proper setting of the selected grading machine, taking into account the effects of all variables that may affect its performance. Results presented in paper 1 regarding visual strength grading this timber species showed lower yield than that obtained in the present one.

According to EN 338 (1996), characteristic values of bending strength, modulus of elasticity and density allow to assign a grade/species/source combination to a strength class, and the other characteristic strength and stiffness properties can be derived from those basic ones. Since mechanical properties in tension parallel to the grain are considered to be important in boards destined for glued laminated timber according to EN 1194 (1999) and researchers (Glos and Diebold 1994; Glos and Lederer 2000; Görlacher 1990), boards of Sample 6 were tested in tension to check the efficiency of the models analysed in profiles a) and b) of Table 2 in relation to these mechanical properties. For this purpose, equivalent values for global modulus of elasticity $\left(\mathrm{E}_{\mathrm{m}, \mathrm{g}}\right)$ and modulus of elasticity in tension parallel to the grain $\left(\mathrm{E}_{\mathrm{t}, 0}\right)$ were assumed, and $\mathrm{E}_{\mathrm{m}, \mathrm{g}}$ was replaced with $\mathrm{E}_{\mathrm{t}, 0}$ in all models. A detailed analysis shows that the mean value is $4 \%$ greater for $\mathrm{E}_{\mathrm{t}, 0}\left(13500 \mathrm{~N} / \mathrm{mm}^{2}\right)$ than for $\mathrm{E}_{\mathrm{m}, \mathrm{g}}\left(13000 \mathrm{~N} / \mathrm{mm}^{2}\right)$ with coefficients of variation of 0.20 and 0.19 respectively. In both cases the values correspond to the specimens free of visual characteristics exceeding the limits established in prEN 14081 for strength classes above C18, which are
135 and 255 pieces for tension and bending respectively. Glos and Lederer (2000) found mean values of $14000 \mathrm{~N} /$ $\mathrm{mm}^{2}$ and $14100 \mathrm{~N} / \mathrm{mm}^{2}$ with coefficients of variation of 0.18 and 0.13 for modulus of elasticity in tension and bending respectively, in a test series with beech in structural sizes. Johansson et al. (1992) reported a mean value for modulus of elasticity $1 \%$ greater in tension than in bending in a test series with Swedish Picea abies, whereas the mean value was $8 \%$ higher in bending than in tension for German Picea abies. In line with the last result, Burger and Glos (1995) found for European spruce a mean value $9 \%$ higher in bending than in tension.

The strength, stiffness, density and yield values for boards of Sample 6 are shown in Table 4. The yield is similar to those corresponding for specimens subjected to bending tests (see also tables 2 and 3), with 85 and 43 specimens in the first and second grade for profile a), which represents $63 \%$ and $32 \%$ of the graded specimens respectively. This model allows to assign, consequently, 95\% of the graded pieces to the two expected grades. Profile b), where the modulus of elasticity in tension parallel to the grain acts as grading parameter, exhibits low differences in yield in comparison with profile a), in line with those found in Table 2 and 3 for bending specimens. The relation between the lower 5 th percentiles for tensile strength of the analysed grades with those found for bending strength (lower 7.5th percentiles) are: $22.2 / 35.9=0.62, \quad 16.2 / 25.7=0.63,11.9 / 19.6=0.61,23.7 /$ $35.7=0.66,15.9 / 25.7=0.62$ and $9.5 / 19.6=0.48$. The value is significantly low in the last case, but it is necessary to find the reason in the small size of the specimens (19) in the third grade of pieces subjected to tension tests (see Table 4). According to these results, the relationship between tensile and bending strength compares well with the value of 0.6 established in EN 384 (1996), confirming the effectiveness of the proposed models for machine strength grading this sawn timber species according to the European standards. 


\section{Conclusions}

The usefulness of single as well as combined parameters for machine strength grading sawn timber of Argentinean Eucalyptus grandis was analysed through a test series with specimens in structural sizes subjected to bending. The combination of modulus of elasticity with density and knot ratio produces the highest correlation with strength, but a very good relationship was also found between strength and global modulus of elasticity by itself. Strength, stiffness and density profiles based on both the combined grading parameter and the modulus of elasticity were analysed, and very good yield was obtained in both cases. It is possible to assign more than $60 \%$ of the graded specimens to the optimum grade (C35) and more than $30 \%$ to the second one $(\mathrm{C} 24)$. A great amount of pieces can not be assigned to strength classes above $\mathrm{C} 18$ because of the presence of large fissures. The presence of these defects also significantly reduces the correlation between the grading parameters and strength and, consequently, accounts for the necessity of improving the drying processes. Both models proposed for strength grading this sawn timber species were also applied to a sample of boards subjected to tension tests and their effectiveness was proved with similar yield than the one found for bending specimens. The results obtained encourage further studies regarding two goals. The first one connected with the possibility of assigning an important number of specimens to a strength class higher than $\mathrm{C} 35$ on the base of a larger number of tests than those made in this research and a consequent lower statistical penalisation for sample size according to EN 384 (1996). The second one related to the development of different models for strength grading beams and boards, with the aim to take advantage of the higher correlation between grading parameters and strength found in some cases for beams and boards separately than for the whole sample.

\section{References}

Blaß HJ, Görlacher R (1996) Visuelle und maschinelle Festigkeitssortierung von Vollholz. Mikado 5:64-71

Burger N, Glos P (1995) Verhältnis zwischen Zug- und BiegeElastizitätsmoduln von Vollholz. Holz Roh- Werkstoff 53:7374
Comité Europeo de Normalización (1997) UNE-EN 1310, Madera aserrada y madera en rollo. Método de medida de las singularidades. AENOR, Madrid

Diebold R (1997) Möglichkeiten der maschinellen Holzsortierung mit dem Euro-GreComat. In: Grazer Holzbau-Fachtagung, Sortierung und Festigkeit, B/1:1-19

Diebold R, Glos P (1994) Verbesserte Holznutzung durch neuartige maschinelle Festigkeitssortierung. Holz Roh- Werkstoff 52:222

Europäisches Komitee für Normung (1996) DIN EN 338, Bauholz für tragende Zwecke, Festigkeitsklassen. Beuth Verlag, Berlin

Europäisches Komitee für Normung (1996) DIN EN 384, Bauholz für tragende Zwecke, Bestimmung charakteristischer Festigkeits-, Steifigkeits- und Rohdichtewerte. Beuth Verlag, Berlin

Europäisches Komitee für Normung (1999) DIN EN 1194, Holzbauwerke, Brettschichtholz, Festigkeitsklassen und Bestimmung charakteristischer Werte. Beuth Verlag, Berlin

European Committee for standardization (2000) Draft prEN 140811, Timber structures - strength graded structural timber with rectangular cross section-part 1: general requirements. CEN, Brussels

Glos P (1995) Strength grading. Timber Engineering STEP 1. Centrum Hout, The Netherlands, pp A6/1-A6/8

Glos P, Burger N (1998) Maschinelle Sortierung von frisch eingeschnittenem Schnittholz. Holz Roh- Werkstoff 56:319329

Glos P, Diebold R (1987) Einfluß verschiedener Sortierbedingungen auf die Biegefestigkeit von Bauholz (Kantholz). Abschlußbericht 84510, Holzforschung München, Technische Universität München

Glos P, Diebold R (1994) Verfahrensentwicklung und Erprobung zur maschinellen Schnittholzsortierung. Abschlußbericht 89505, Institut für Holzforschung der Universität München

Glos P, Lederer B (2000) Sortierung von Buchen- und Eichenschnittholz nach der Tragfähigkeit und Bestimmung der zugehörigen Festigkeits- und Steifigkeitskennwerte. Bericht Nr. 98508, Institut für Holzforschung, München

Görlacher R (1997) Möglichkeiten der maschinellen Holzsortierung mit dem GradeMaster 403. In: Grazer Holzbau-Fachtagung, Sortierung und Festigkeit, B/2:1-10

Görlacher R (1990) Sortierung von Brettschichtholzlamellen nach DIN 4074 durch Messung von Longitudinalschwingungen. Bauingenieur 65:517-522

Johansson CJ, Brundin J, Gruber R (1992) Stress Grading of Swedish and German Timber, a comparison of machine stress grading and three visual grading systems. SP Report 1992:23, Swedish National Testing and Research Institute, Sweden

Piter JC, Zerbino RL, Blaß HJ (2004) Visual strength grading of Argentinean Eucalyptus grandis. Strength, stiffness and density profiles and corresponding limits for the main grading parameters. Holz Roh- Werkstoff (in press)

Sauter UH, Diebold R (1997) Steigerung der Ausbeute von Kiefern-Brettlamellen hoher Tragfähigkeit durch maschinelle Festigkeitsortierung. Holz Roh- Werkstoff 55:237-244 